Мацько Любов Іванівна, доктор філологічних наук, академік НАПН України, професор, завідувач кафедри стилістики української мови Інституту української філології Національного педагогічного університету імені М. П. Драгоманова, м.Київ, e-mail: iuf@npu.edu.ua

Кудіна Тамара Миколаївна, викладач української мови кафедри загальноосвітніх дисциплін Інституту дистанційного навчання Національного педагогічного університету імені М. П. Драгоманова, м.Київ, e-mail: kudina@npu.edu.ua

\title{
МЕРЕЖЕВИЙ НАВЧАЛЬНО-МЕТОДИЧНИЙ КОМПЛЕКС ВИВЧЕННЯ УКРАЇНСЬКОЇ МОВИ ЯК ІНОЗЕМНОЇ
}

\begin{abstract}
Анотація
Зважаючи на недостатню кількість часу навчання іноземців, що вперше вивчають українську мову на підготовчих відділеннях університетів, створено
\end{abstract} мережевий навчально-методичний комплекс для навчання української мови. Відмінною особливістю комплексу є його інтернет-адаптованість: складові елементи комплексу розміщені на сайті Інституту дистанційного навчання (www.idn.npu.edu.ua), що створює можливість цілодобового доступу. Комплекс, який складається $з$ колекції «відібраних» україномовних фільмів, мультимедійного банку інтерактивних діалогів, перекладного словника і тлумачного аудіословника, разом із навчальним посібником є курсом для вивчення української мови як іноземної.

Ключові слова: українська мова як іноземна, мережевий навчальнометодичний комплекс, інтернет-адаптований, мультимедійний, самонавчання.

Постановка проблеми. Інтеграція України у світовий простір привела до зростання інтересу іноземців до здобуття освіти в українських вищих навчальних закладах. Через те, що викладання у ВНЗ ведеться українською мовою, згідно 3 існуючим законодавством в Україні, студентом українського ВНЗ може стати тільки той іноземець, який вивчив державну мову на підготовчому факультеті й отримав відповідний сертифікат. Національний педагогічний університет імені М. П. Драгоманова має ліцензію, що дає право видавати такий документ, і довгий час 
займається такою діяльністю (3 2004 року). Багаторічний досвід викладання української мови як іноземної показав, що працюючи з традиційними підручниками 18 годин на тиждень, відведених чинною навчальною програмою [1] над засвоєнням мови, яка повинна стати засобом оволодіння професією, іноземці, що приїхали з країн Сходу чи Африки і вперше зіткнулися із зовсім іншою мовною системою, повільно, 3 великими труднощами входять в україномовне середовище. Проблему ускладнює i той факт, що поза університетом, у громадських місцях Києва, знайти україномовного співрозмовника теж важко.

Як відомо, єдиним найбільшим середовищем для спілкування сучасної молоді є Інтернет. Та огляд існуючих сайтів, де викладені навчальні курси української мови, свідчить, що їх дуже мало. Так, до основних сайтів, на яких можна знайти навчальні матеріали з української мови, належать ті, що показані на рис. 1-3.

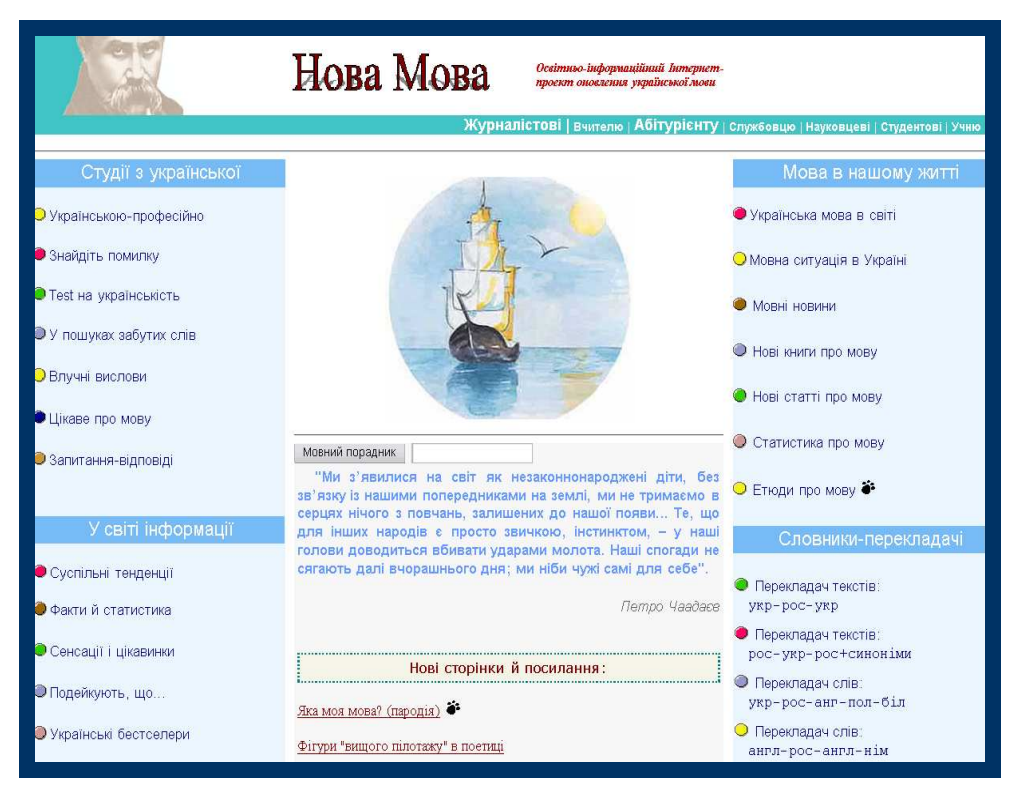

Рис. 1. Головна сторінка сайту «Нова мова» (http://www.novamova.com.ua) 


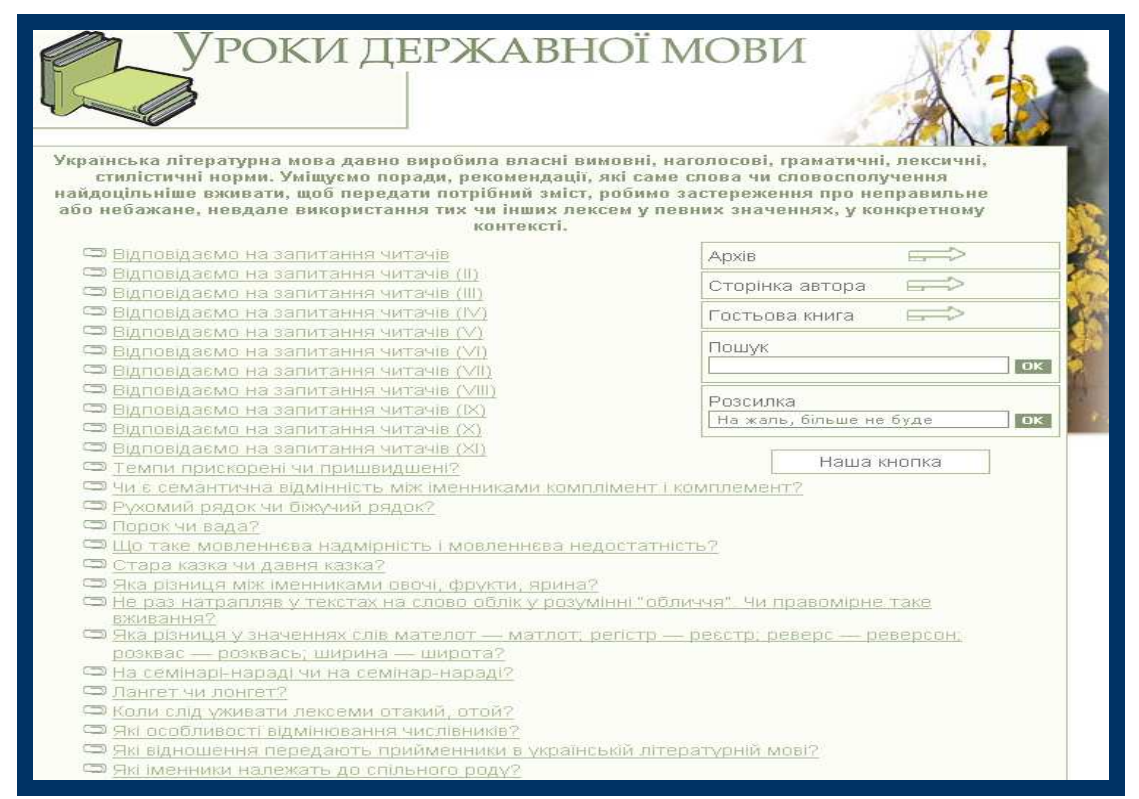

Рис. 2. Головна сторінка сайту «Уроки державної мови» (http://www.mova.kreschatic.kiev.ua)

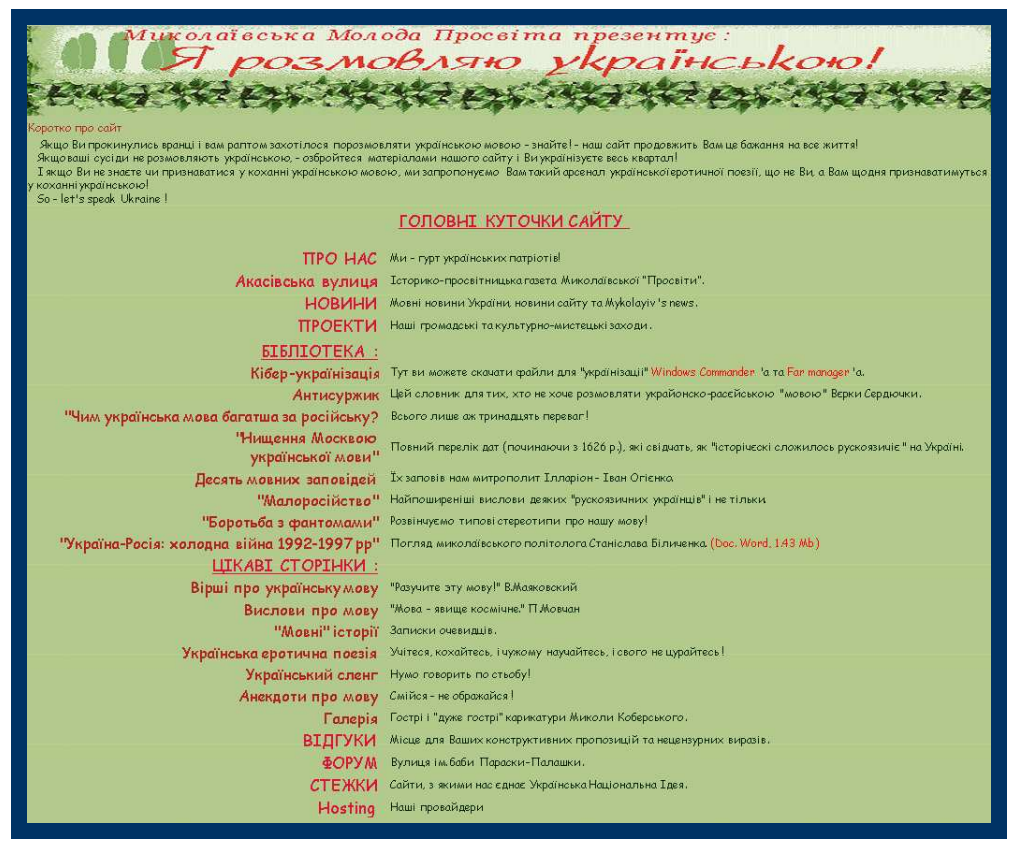

Рис. 3. Головна сторінка сайту «Я розмовляю украӥнською!» (http://www.arkasproswita.iatp.org.ua)

Аналіз змістового наповнення цих сайтів свідчить про те, що на них не можна побудувати поурочний навчальний процес, вони не придатні для навчання іноземців. На сайті Львівського національного університету імені Івана Франка [2] розміщено в основному інформаційні матеріали з курсу «Українська мова як іноземна». Деякий 
інтерес представляє система тестів для перевірки рівня володіння українською мовою іноземцями, які мають намір вступити до ВНЗ України. На сайті Києво-Могилянської академії [3] викладений курс української мови як іноземної для англомовних слухачів. В основі курсу лежить перекладний метод. I хоча зразки діалогів, текстів мають аудіосупровід, та досягнути повної семантизації лексичного матеріалу одним перекладом неможливо.

Тому метою наших досліджень стала розробка інтернет-адаптованого навчально-методичного забезпечення, що відповідає дидактиці вивчення української мови як іноземної і дозволяє слухачеві підготовчого відділення збільшити час спілкування українською мовою в рамках єдиного навчального курсу і єдиного навчального процесу, автором якого і модератором якого є один викладач української мови.

Основний матеріал. Як відомо, процес пізнання інтерпретується як відображення об'єктивної дійсності в нашій свідомості. Відображення починається 3 відчуття, без якого неможливе формування у свідомості якихось понять, образів, знань. Однак органи чуття людини мають різну здатність до сприйняття інформації. На рис. 4 наведено їх порівняльну характеристику [4]. Видно, що найбільший відсоток у сприйнятті інформації має зір (83\%). Тобто око є найширшим каналом, через який інформація від об’ єкта пізнання прямує до свідомості.

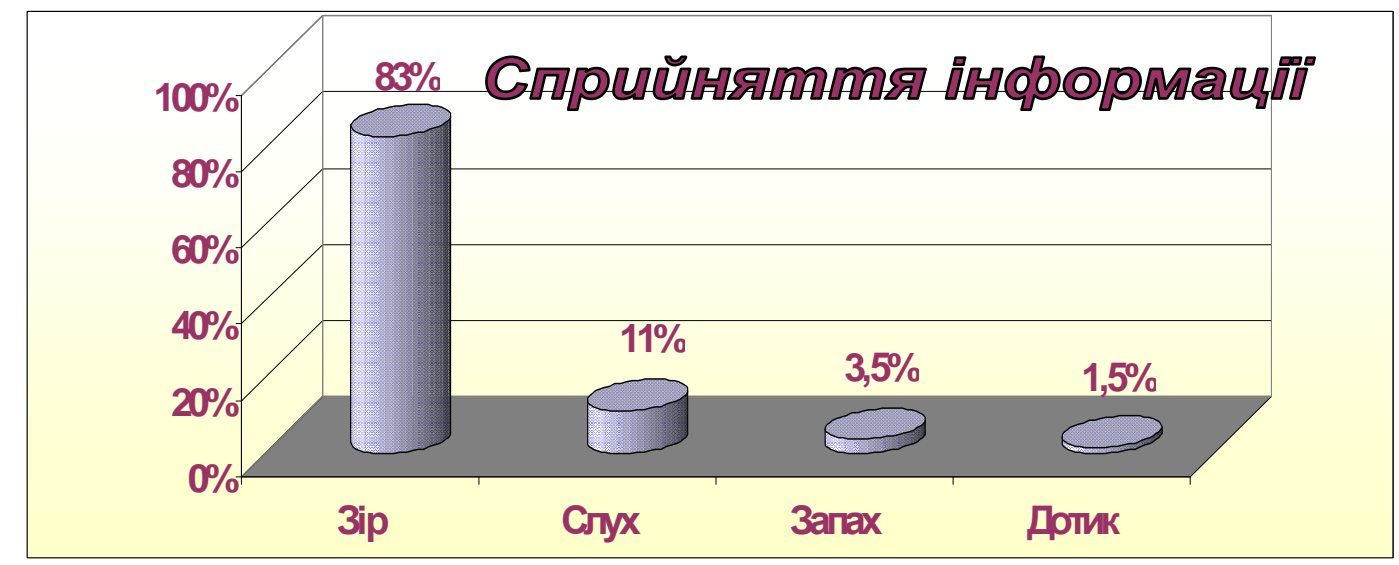

Рис. 4. Порівняльна характеристика сприйняття інформаџії

Представлений розподіл на рис. 4 пояснюється тим, що 34 млн. нервових закінчень, які передають інформацію в людському організмі, близько 2 млн. припадає на зір і лише 60 тис. - на слух. Через це пропускна здатність зорового каналу 
сприйняття інформації є набагато вищою за пропускну здатність слухового каналу (приблизно в 7,5 разів). Тому візуальна форма представлення інформації є набагато продуктивнішою.

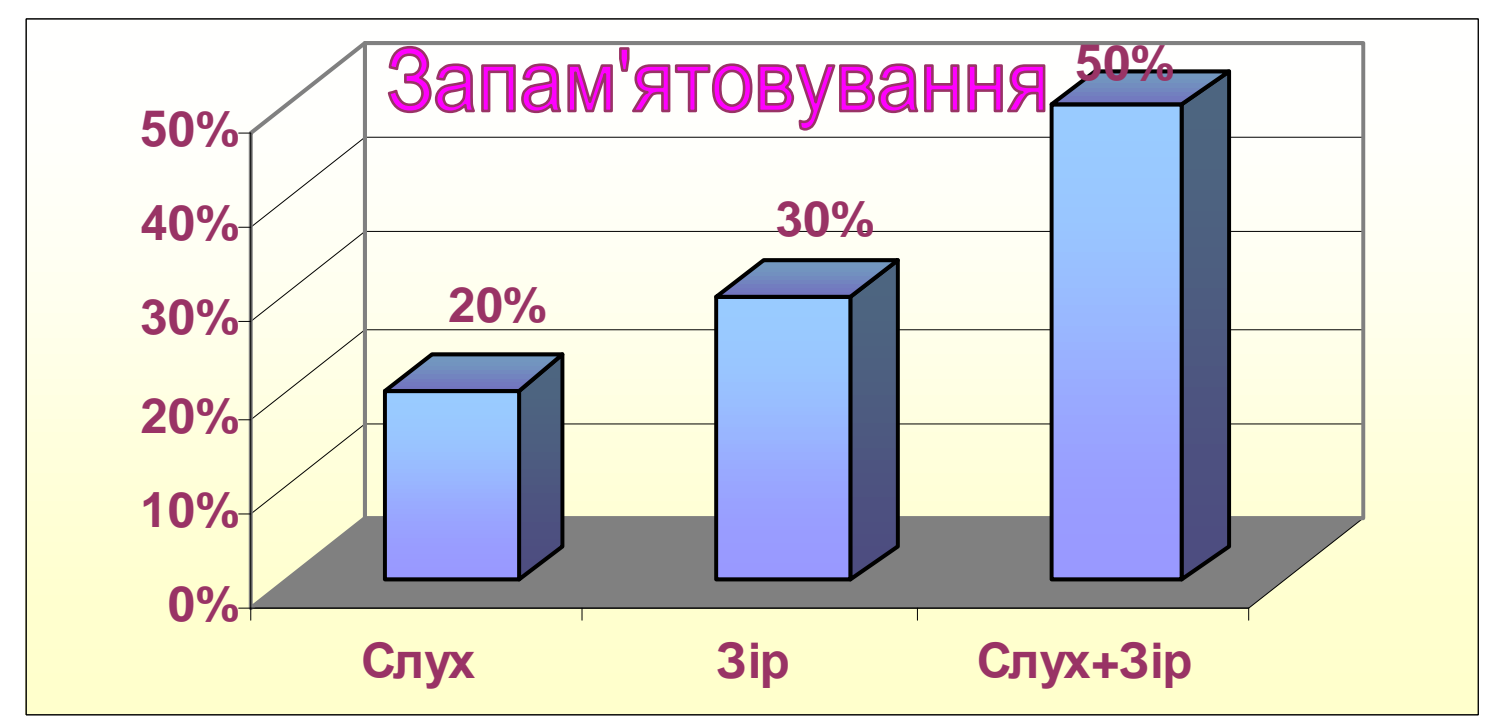

Рис. 5. Порівняльна характеристика запам'ятовування інформації

3 наведених на рис. 5 діаграм видно, що найбільше запам'ятовування спостерігається при поєднанні зорового і слухового каналів. Тобто найбільш ефективне сприйняття інформації спостерігається при поєднанні вербальної i візуальної форм іiі подання, яке забезпечується мультимедійними засобами навчання. Це спонукало до створення мережевого навчально-методичного комплексу (МНМК) для позааудиторного навчання, який складається 3 таких елементів:

1. Колекція «відібраних» україномовних фільмів.

2. Мультимедійний банк інтерактивних діалогів.

3. Тлумачний аудіословник.

Наведемо короткий аналіз елементів МНМК.

\section{1. Колекція «відібраних» україномовних фільмів.}

Звичайно, ядро навчального курсу складають україномовні фільми, які вільно розповсюджені в Інтернеті [5]. Необхідно зазначити, що не всі фільми, на нашу думку, відповідають дидактичним вимогам викладання української мови як іноземної. 3 наведеної табл. 1 видно, що фільми групи А - це історичні фільми, які вимагають, окрім розуміння мови, ще й розуміння історії України, якої іноземці не знають. Аудіоряд таких художніх фільмів насичений архаїзмами й історизмами. Це лексика 
обмеженого вживання, 3 якою слухачі підготовчого факультету не знайомляться. Отже, фільми групи А не відповідають дидактичним цілям.

Таблиця 1

Інтернет-доступні україномовні фільми (приклади)

\begin{tabular}{|l|ll|}
\hline Тип фільму & Назва фільму, рік випуску \\
\hline А & 1. & «Ярослав Мудрий», 1981. \\
& 2. & «Пропала грамота», 1972. \\
& 3. & «Богдан-Зіновій Хмельницький», 2008 \\
\hline Б & 1. & «Тіні забутих предків», 1964. \\
& 2. & «Камінний хрест», 1968. \\
& 3. & «Біла птаха з чорною ознакою», 1970 \\
\hline В & 1. & «Аліса в країні чудес», 2010. \\
& 2. & «З Парижа з любов'ю», 2010 \\
\hline Г & 1. & «Вавилон ХХ», 1979. \\
& 2. & «Гріх», 1991. \\
& 3. & «Дім батька твого», 1986. \\
& 4. & «Украдене щастя», 2004 \\
\hline
\end{tabular}

У фільмах групи Б актори ведуть діалоги, використовуючи діалектну лексику. У художньому мовленні діалектизми використовуються як важливий засіб зображення місцевого колориту, специфіки побуту, як засіб передачі індивідуального мовлення героїв. Та іноземцям такі кінодіалоги будуть зовсім не зрозумілими.

Фільми групи В - іноземного виробництва, дубльовані. Заміна текстової частини звукового фільму перекладом на українську мову не передає етнічних особливостей мовлення українців, адже актори - носії іншої мови.

Фільми групи Г відібрані нами як оптимальні з навчальних позицій: є наочним лінгводидактичним матеріалом, у якому органічно поєднуються глобальність сюжетного потоку відеоінформації і дискретна природа епізодів, які складають сюжет і які, у свою чергу, складаються 3 типових ситуацій, що дозволяють «монтувати» мовленнєві зразки літературної мови, необхідні для осмислення і засвоєння. Фільми групи Г і складають перший компонент МНМК. Колекція викладена на сайті Інституту дистанційного навчання (www.idn.npu.edu.ua) i тим самим може бути доступна іноземцям через мережу Інтернет. Планується постійне поповнення цієї колекції україномовних фільмів. Звичайно, це можуть бути і мультиплікаційні фільми, розважальні програми тощо. 


\section{2. Мультимедійний банк інтерактивних діалогів.}

Мультимедійний банк інтерактивних діалогів виконаний у вигляді інтерактивної електронної книги у програмному продукті Camtasia Studio (розробник: TechSmith Corporation), яка складена 3 фрагментів фільму із синхронізованими слайдами. Іншим варіантом технічного вирішення є Producer Microsoft. Необхідно зазначити, що сфера застосування цих продуктів, за повідомленнями [6], досить широка: створення інтерактивних файлів довідок, демонстрації можливостей програм, запису типом «захвату» 3 екрана, демонстрації роликів і т. п.

Якщо в колекції на сайті можна переглянути фільм повністю, то в цьому елементі навчально-методичного комплексу знаходяться кінофрагменти-діалоги. Кожен кінофрагмент задає тему заняття, вводить необхідну лексичну базу, стимулює вивчення певних граматичних структур і культурологічних феноменів.

Інтерфейс продукту 3 екрана монітора має такий вигляд: демонстрація кінодіалогів здійснюється на лівому екрані (рис. 6), який має програвач (внизу), що дозволяє зупиняти, повертатися назад до фрагмента.

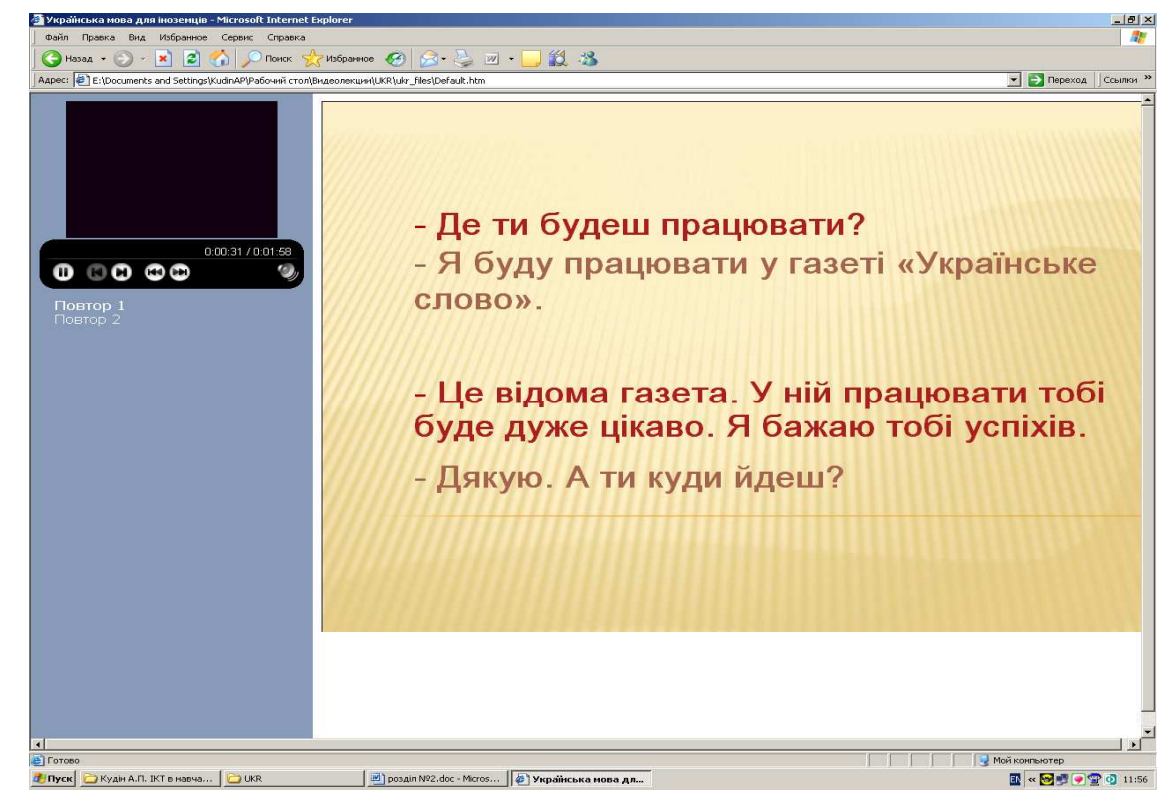

Рис. 6. Мультимедійний банк інтерактивних діалогів

Вибір діалогів (тем занять) здійснюється через ліве нижнє поле (рис. 6). Текст кінодіалогу демонструється у правому вікні, причому появу реплік кожного співрозмовника синхронізовано 3 «проголошенням» цієї репліки героєм епізоду фільму, який демонструється на лівому екрані. Крім того, репліки героїв відрізняються кольорами, що полегшує ідентифікацію дійової особи. 
Саме текст кінодіалога служить основою для формування навичок аудіювання, для роботи над правильною вимовою, інтонацією.

\section{3. Тлумачний аудіословник.}

Тлумачний словник - необхідний для самонавчання елемент курсу, бо дає інформацію про нові слова, що зустрічаються у тексті. Технічно він реалізований як «підказка» - вікно, що випливає, коли на слово наводиться курсив. Цей елемент МНМК можна ефективно використовувати в аудиторній лекції для інтерактивного опитування й активізації пізнавальної діяльності слухачів.

Дослідження психічних механізмів мовлення показали: якщо людина, яка слухає нерідну мову, не буде декодувати звуковий склад почутого слова на рухи мовного апарату, вона не зможе «впізнати» лексичну одиницю. Ідентифікація слова в іншомовному висловлюванні можлива лише за умови, що ця лексична одиниця знайома слухачеві. Тому у програмному продукті «Тлумачний аудіословник» $\epsilon$ можливість багаторазового прослуховування - вмонтовано - плеєр. Плеєр обов'язковий елемент словника, бо іноземець повинен нове слово чути і мати можливість повторити його за мовцем кілька разів.

Мережевий навчально-методичний комплекс доповнюється навчальним посібником «Українська мова для іноземців. Практичний курс», що є текстовим додатком. Матеріал навчального посібника розбитий на уроки. Кожен урок включає в себе, крім графічного тексту діалогів, лексичний матеріал (тлумачний і перекладний словники), вправи, додаткові тексти для читання, необхідний граматичний матеріал, контрольні завдання.

Висновки. Отже, застосування розробленого МНМК разом 3 навчальним посібником приводить до збільшення часу перебування іноземця в україномовному середовищі за рахунок створених і викладених в Інтернеті засобів для самонавчання, що тісно пов'язані з курсом, який викладається в аудиторії. Важливо і те, що збільшення часу навчання іноземця не приводить до перевантаження викладача.

Найголовнішим у будь-якому навчальному засобі $\epsilon$ його доступність. Необхідно відзначити, що всі вище перераховані елементи навчально-методичного комплексу виготовлені з інтернет-адаптованих програмних продуктів.

Подальшого розвитку потребує доповнення тлумачного словника засобами самостійної корекції вимови слів. Технічно це може бути реалізовано за допомогою 
візуального еквалайзера, який демонструє два звукові записи - еталонний і студента. У результаті накладання студент бачить відмінності і починає у повторних записах «підлаштовувати» свій сигнал до еталонного. Це свого роду корекція вимови іншомовного слова шляхом самонавчання.

\section{Список використаних джерел}

1. Навчальні плани та програми (довузівська підготовка іноземних громадян) / уклад. : Л. Г. Новицька, О. Ф. Гудзенко, М. І. Дудка та ін. - К. : ІВЦ «Видавництво «Політехніка», 2003. - Ч. 1. - 56 с.

2. Сайт «Мовний калейдоскоп» [Електронний ресурс]. - Режим доступу: http://www.franko.jviv.ua/knp/mova/index.htm.

3. Сайт «Києво-Могилянська академія» [Електронний ресурс]. - Режим доступу : http://www.ukma.kiev.ua/ ua/pub/websites/ufl/index.htm.

4. «Теоретические сведения. Библиотека статей по психологии» [Електронний pecypc]. — Режим доступу : http://www.effecton.ru/04.html.

5. Сайт «Банк українських фільмів» [Електронний ресурс]. - Режим доступу : http://www.google. com.ua/search?g.

6. Сайт «TechSmith Learning Center» [Електронний ресурс]. - Режим доступу : http://www.techsmith.com.

\section{СЕТЕВОЙ УЧЕБНО-МЕТОДИЧЕСКИЙ КОМПЛЕКС ОБУЧЕНИЯ УКРАИНСКОМУ ЯЗЫКУ КАК ИНОСТРАННОМУ}

Мацько Любовь Ивановна, доктор филологических наук, академик НАПН Украины, профессор, заведующий кафедрой стилистики украинского языка Института украинской филологии Национального педагогического университета имени М. П. Драгоманова, г. Киев, e-mail: iuf@npu.edu.ua

Кудина Тамара Николаевна, преподаватель украинского языка кафедры общеобразовательных дисциплин Института дистанционного обучения Национального педагогического университета имени М. П. Драгоманова, г.Киев, еmail:kudina@npu.edu.ua

\section{Аннотация}


Учитывая недостаток учебного времени у иностранцев, которые впервые изучают украинский язык на подготовительных отделениях университетов, создано сетевой учебно-методический комплекс для обучения украинскому языку. Отличительной особенностью комплекса есть интернет-адаптированность: составляющие элементы находятся на сайте Института дистанционного обучения (www.idn.npu.edu.ua), что создает возможность круглосуточного доступа. Комплекс, состоящий из коллекции «отобранных» украиноязычных фильмов, мультимедийного банка интерактивных диалогов, переводного словаря и толкового аудиословаря, вместе с учебным пособием представляет собой курс для изучения украинского языка как иностранного.

Ключевые слова: украинский язык как иностранный, учебно-методический комплекс, интернет-адаптированный, мультимедийный, самообучение.

\section{NETWORK EDUCATIONAL AND METHODICAL COMPLEX FOR LEARNING UKRAINIAN AS A FOREIGN LANGUAGE}

Lyubov I. Mats'ko, Ph.D., academician of NAPN of Ukraine, professor, head of the Department "Stylistics of Ukrainian language" of the Institute of Ukrainian Philology of National Pedagogical University named after Mykhailo Dragomanov, Kyiv, e-mail: iuf@npu.edu.ua

Tamara N. Kudina, Ukrainian language teacher of the Department of General Studies of the Institute of Distance Learning of National Pedagogical University named after Mykhailo Dragomanov, Kyiv, e-mail: kudina@npu.edu.ua

\section{Resume}

Given the shortage of training time for foreigners, who first-time study the Ukrainian language in the preparatory departments, networking educational and methodical complex for Ukrainian language learning was created. This complex is fully Internet adapted and together with tutorial - is a course for learning Ukrainian as a foreign language. The distinctive feature of the complex has an adaptation for Internet: the constituent elements are on the website of the Institute of Distance Learning (www.idn.npu.edu.ua), which creates the possibility of around the clock access. Complex consisting of collection of "selected" Ukrainian films, multimedia bank of interactive dialogues, translation and 
explanatory audio dictionary, together with the textbook is the Course for learning Ukrainian as a foreign language.

Keywords: Ukrainian as a foreign language, educational and methodical complex, Internet adapted, multimedia, self-education.

Матеріал надійшов до редакції 28.02.2011 р. 